\title{
METÓDY VIACNÁSOBNÉHO PRÍSTUPU V PROSTREDÍ RFID
}

\author{
Juraj Vaculík ${ }^{1}$
}

\section{Úvod.}

V prevádzke RFID systémov sa preto často vyskytuje situácia, pri ktorej je identifikátor snímaný viacerými čítačkami alebo je vel'ké množstvo identifikátorov prítomných $\mathrm{v}$ prijímacej zóne jedného snímača $\mathrm{v}$ rovnakom čase. $\mathrm{V}$ prvom prípade je situácia jednoduchšia a dá sa ošetrit' na nadstavbovej aplikácií, kde je možné identifikovat', ktorá anténa, resp. čítačka identifikátor načítala, alebo fyzickým oddelením čítačiek. V druhom prípade v takom systéme, pozostávajúcom z riadiacej stanice, snímača a určitého počtu zúčastnených identifikátorov - môžeme rozlišovat' dve hlavné formy komunikácie.

Prvá sa používa pre prenos údajov z vysielača (čítačky) do identifikátorov (obr.1). V tomto prípade je tok prenesených dát prijatý všetkými identifikátormi súčasne. To je porovnatel'né so súčasným príjmom programu správ stovkami rozhlasových prijímačov prenášaného rozhlasovou stanicou. Tento typ komunikácie je preto známy ako vysielanie.

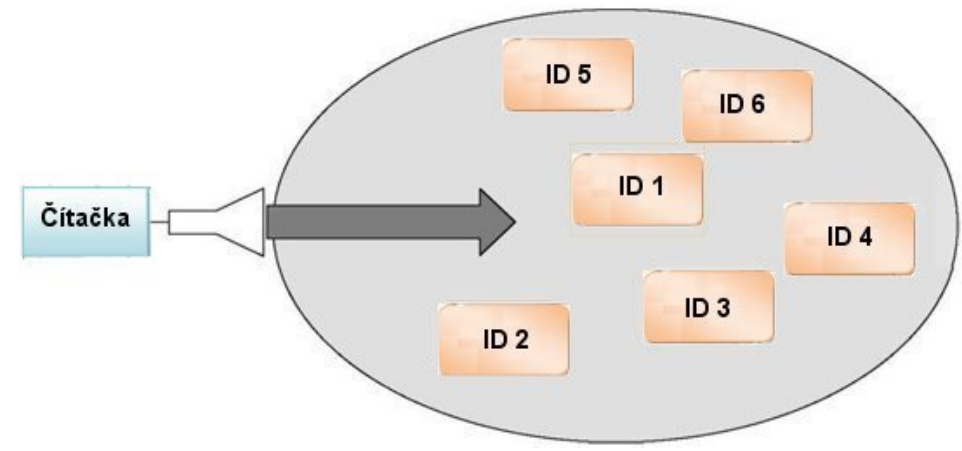

Obr. 1. Vysielací mód

K tomu, aby RFID čítačka pre identifikáciu mnohých značiek vo svojom čítacom rozsahu pracovala, musí pracovat' $\mathrm{s}$ identifikátormi $\mathrm{v}$ čom je známa ako antikolízny singulation (mimoriadny) protokol. Ak začnú všetky značky v dosahu čítačky odovzdat' dáta súčasne, potom sa ich signály dostanú do rozporu medzi sebou, interpretácia čítania je neúčinná. Singulation protokol rieši tento problém tým, že umožňuje značkám striedat' sa pri prenose na čítačku. U značky UHF singulation je všeobecný variant protokolu, známy ako strom-walking (prechod stromom). Stručne povedané, že v prechádzajúcom „strome“, je priestor k pár identifikátorom vnímané ako lístie na strome $\mathrm{v}$ híbke. Čítačka prechádza strom a žiada podmnožiny značiek vysielat' jediný bit v čase. Funkcia základného prechodu stromom je to, že RFID čítačka vysiela

\footnotetext{
${ }^{1}$ doc. Ing. Juraj Vaculík, PhD., Žilinská univerzita, fakulte PEDAS, katedra spojov, Univerzitná 1, Žilina, mail: juvac@fpedas.uniza.sk, tf: +421 415133132
} 
záznam sériových čísel na vel'mi vel'ké vzdialenosti, čo môže predstavit' náchylnost' $\mathrm{k}$ odpočúvaniu.

Druhá forma komunikácie zahŕňa prenos dát $\mathrm{z}$ množstva jednotlivých identifikátorov $\mathrm{v}$ prijímacej zóne snímača do čítačky. Táto forma komunikácie sa nazýva multi-access (viacnásobný príjem obr.2). Každý komunikačný kanál má zadefinovanú kapacitu kanála, ktorá je určená podl’a maximálnej prenosovej rýchlosti tohto komunikačného kanála a časového rozsahu jeho dostupnosti. Dostupná kapacita kanála, musí byt' rozdelená medzi jednotlivých účastníkov (identifikátory) a to tak, že údaje môžu byt' prenesené z niekol'kých identifikátorov do jedného snímača bez vzájomného rušenia (kolízie).

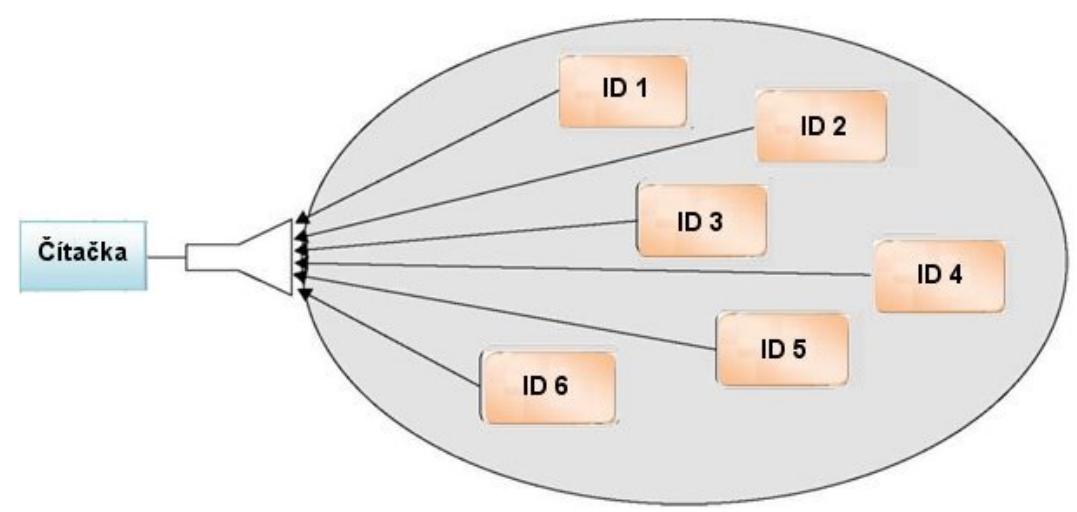

Obr. 2. Multi-access (viacnásobný príjem) čítačkou

Technická realizácia procesu multi-access v systémoch RFID predstavuje niekol'ko nárokov na identifikátor a snímač, pretože musí spol'ahlivo zabránit' aby sa údaje (pakety) identifikátorov nedostávali do kolízie s druhými údajmi v prijímači snímača čítačky a tak sa stávali nečitatelnými a to všetko bez toho aby to spôsobilo zistitel'né omeškanie. V súvislosti s RFID systémami sa technický postup (prístupový protokol), ktorý ul'ahčuje manipuláciu viacnásobného prístupu bez akéhokol'vek vonkajšieho zasahovania, nazýva antikolizný systém. Skutočnost', že paket dát odoslaný snímaču jedným identifikátorom sa nedá prečítat' ostatnými identifikátormi $\mathrm{v}$ prijímacom pásme tohto snímača predstavuje problém pre takmer všetky RFID systémy. Z tohto dôvodu identifikátor nemôže odhalit' prítomnost' iných identifikátorov v prijímacej zóne snímača.

\section{Metóda SDMA}

Termín SDMA (obr. 3) sa týka techniky, ktorá opakovane použiva určitý zdroj (kapacitu kanála) v priestorovo oddelených oblastiach. Jednou z možností je výrazne znížit’ rozsah jedného snímača, ale kompenzovat' to tým, že sa spojí vel'ký počet snímačov a antén vo forme pol’a a tak sa zabezpečí pokrytie požadovaného priestoru. V dôsledku toho je kapacita kanála u susediacich snímačov opakovane $\mathrm{k}$ dispozícii. Tieto postupy boli úspešne použité pri vel'kých maratónskych sút'ažiach pre určenie času trvania behu maratónskych bežcov vybavených identifikátormi. V tomto prípade bolo do rohože zabudovanej v bežeckej dráhe vložené množstvo antén. Bežec bežiaci ponad rohož si niesol svoj identifikátor nad prijímacou zónou niekol'kých antén, ktoré boli súčast'ou celej schémy. Vel'ký počet identifikátorov bolo teda možné čítat' súčasne ako výsledok priestorovej distribúcie bežcov nad celou schémou.

Ďalšou možnost'ou je použitie elektronicky ovládanej smerovej antény na snímač, smerového lúča ktorý možno priamo zamerat' na identifikátor (adaptívne SDMA). Tak môžu byt' 
rozličné identifikátory rozlíšené podl’a ich uhlovej polohy v prijímacej zóne snímača. Fázové zoradené antény sa používajú ako elektronicky ovládané smerové antény. Tieto pozostávajú z niekol'kých dipólových antén a preto adaptívne SDMA v dôsledku vel'kosti antén možno použit' iba pre RFID aplikácie na frekvenciách nad $850 \mathrm{MHz}$ (Typicky 2,45 GHz). Každý z prvkov dipólu je riadený na určitú nezávislú fázovú pozíciu. Smerový diagram antény sa získa z rôznych superpozícií jednotlivých vín dipólových prvkov v rôznych smeroch. V niektorých smeroch jednotlivých polí dipólovej antény sú znásobené vo fáze, čo vedie k zosilneniu pol’a. V ostatných smeroch vlny úplne alebo čiastočne rušia jedna druhú. Pre nastavenie smeru sa dodáva do jednotlivých prvkov nastavitel'né vysokofrekvenčné napätie a variabilná fáza sa ovláda fázovými modifikátormi. Ak chce snímač nájst' identifikátor, priestor kolo snímača musí byt' skenovaný s použitím smerovej antény pokial' identifikátor nie je detekovaný „hl’adacím svetlom“ snímača. Nevýhodou SDMA techniky sú pomerne vysoké nadobúdacie náklady na komplikovaný anténny systém. Použitie tohto typu protikolízného postupu je teda obmedzený na niekol'ko málo špecializovaných aplikácií.

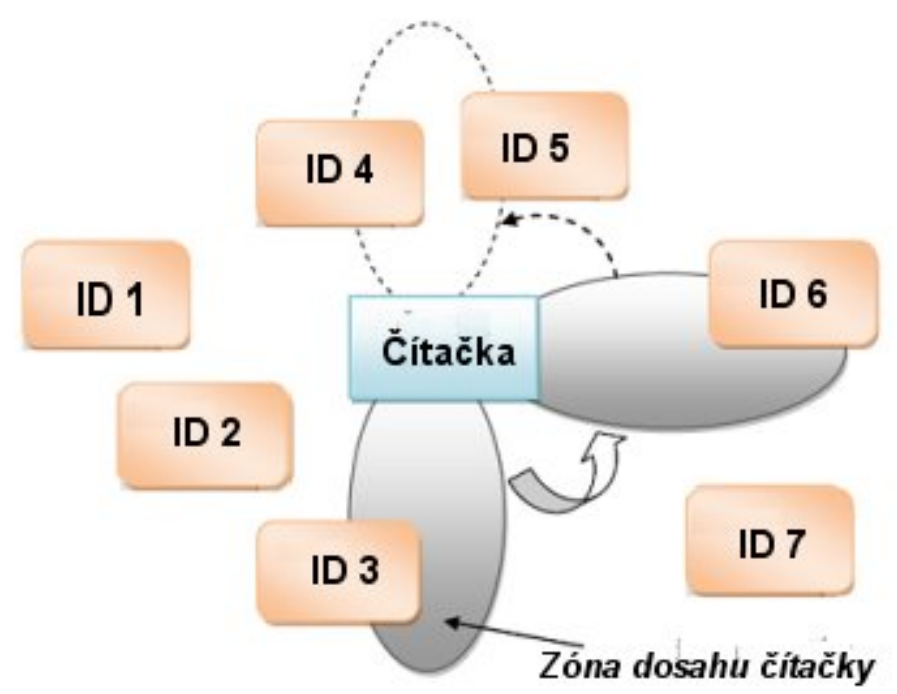

Obr. 3. SDMA s elektricky ovládanou smerovou anténou, smerový lúč je zameriavaný na jednotlivé identifikátory

\section{Metóda FDMA}

Termín FDMA sa týka techník prenosu signálu, pri ktorých je niekol'ko prenosových kanálov na rôznych nosných frekvenciách súčasne k dispozícii komunikačným účastníkom.

V prípade systémov RFID toto môže byt' dosiahnuté pomocou identifikátorov s vol'ne nastavitel'nou, harmonickou prenosovou frekvenciou. Napájanie identifikátoru a prenos riadiacich signálov (vysielanie), sa uskutočňuje na optimálne vhodnej frekvencii snímača čítačky. Identifikátory odpovedajú na jednej z niekol'kých dostupných odpovedajúcich frekvenciách $\mathrm{F}_{1}$ $\mathrm{F}_{\mathrm{n}}$ (obr. 4). Preto môžeme použit' úplne odlišné frekvenčné pásma pre prenos dát $\mathrm{z} / \mathrm{do}$ identifikátorov (napr. snímač $\rightarrow$ identifikátor (Downlink): $135 \mathrm{kHz}$, identifikátor $\rightarrow$ snímač (uplink): niekol'ko kanálov v rozsahu 433 do $435 \mathrm{MHz}$ ). Jednou z možností čítania modulovaných RFID systémov alebo systémov spätného rozptylu je použitie rôznych nezávislých subnosných frekvencií na prenos dát $\mathrm{z}$ identifikátoru do snímača. Jednou z nevýhod postupu FDMA sú pomerne vysoké náklady na snímače, nakol'ko pre každý prijímací kanál musí byt' zabezpečený špecializovaný snímač. Tento antikolízný postup aj nad’alej ostáva obmedzený na niekol'ko špecializovaných aplikácií. 


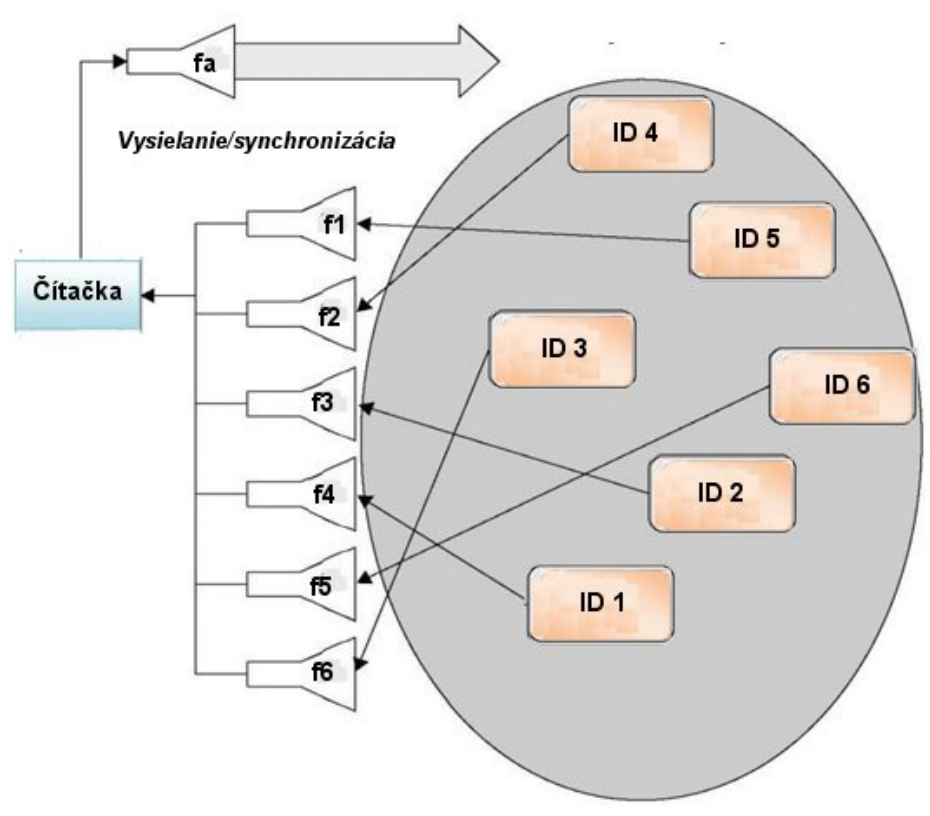

Obr. 4. FDMA postup kde je niekol'ko frekvenčných kanálov dostupných pre prenos dát z identifikátorov do snímača

\section{Metóda TDMA}

Termín TMDA sa týka techník, pri ktorých je celá dostupná kapacita kanála rozdelená medzi účastníkov a je rozdelená chronologicky. TDMA postupy sú rozš́rené najmä v oblasti digitálnych mobilných rádiových systémov. Pri RFID systémoch majú postupy TDMA najväčšiu skupinu antikolíznych postupov. Rozlišujeme medzi postupmi riadenými identifikátormi a čítačkou.

Metódy riadené identifikátormi fungujú asynchrónne, pretože snímač čítačky neriadi prenos dát. To je prípad, ked’ sa používa ALOHA postup. Tiež rozlišujeme medzi „vypnutými“ a „nezapnutými“ postupmi v závislosti na tom, či je identifikátor vypnutý signálom od snímača po úspešnom prenose dát (magellan čipy).

Tieto metódy sú prirodzene vel'mi pomalé a indexovatel'né. Väčšina aplikácií preto používa postupy, ktoré sú ovládané snímačom čítačky ako centrálou (centrálou riadené). Tieto postupy je možné považovat' za synchrónne, nakol'ko všetky identifikátory sú riadené a kontrolované snímačom súčasne. Individuálny identifikátor sa najskôr vyberie z vel'kej skupiny identifikátorov $\mathrm{v}$ prijímacej zóne snímača s pomocou určitého algoritmu a potom dochádza ku komunikácii medzi zvoleným identifikátorom a čítačkou (napr. autentizácia, čítanie a zapisovanie údajov). Až potom je komunikačný vzt’ah ukončený a vybraný je d’alší identifikátor. Napriek tomu že iba jeden komunikačný vzt’ah môže byt' zahájený $\mathrm{v}$ určitom okamihu, identifikátory možno prevádzkovat' v rýchlom slede, centrálou - riadenými postupmi, ktoré sú tiež známe ako duplexné postupy.

Postupy riadené centrálou sú rozdel'ované na prieskumy a postupy binárneho vyhl'adávania. Všetky tieto postupy sú založené na identifikátoroch, ktoré sú identifikované unikátnym sériovým číslom. Prieskumný postup vyžaduje zoznam sériových čísel všetkých identifikátorov, ktoré sa môžu vyskytnút' v aplikácii. Všetky sériové čísla sú preverované snímačom jeden po druhom, kým identifikátor s identickým sériovým číslom neodpovie. 
Tento postup však môže byt' vel'mi pomalý v závislosti od počtu možných identifikátorov a je preto vhodný iba pre aplikácie s niekol'kými, známymi identifikátormi v oblasti. Binárne vyhl'adávacie postupy sú najviac flexibilné a preto najbežnejšie postupy. V binárnom vyhl'adávacom postupe je identifikátor vybraný zo skupiny úmyselne spôsobenou kolíziou dát $\mathrm{v}$ sériových číslach identifikátorov prenášaných do snímača na základe požadovaného príkazu zo snímača. Ak tento postup uspeje je rozhodujúce, že snímač je schopný určit' presnú pozíciu bitu kolízie použitím vhodného kódovacieho systému signálu.

\section{Záver}

Príspevok sa zaoberá teoretickými a praktickými problémami pri riešení antikolíznych situácií, či už na strane čítačiek alebo na strane identifikátorov. V praxi ale môžu byt' tieto vlastnosti využité aj iným spôsobom, hlave $\mathrm{v}$ oblasti testovania systémov, monitorovania a vyhodnocovania niektorých charakteristík tejto technológie ako čitatel'nost', čítací dosah, spol'ahlivost' čítania h a d'alších.

\section{Literatúra}

[1] KOLAROVSZKI, P. - MICHÁLEK, I.: Zásady implementácie a integrácie RFID v prostredí Supply chain manažmentu. In: Svět informačních systémů 2008, medzinárodná konferencia. Zlín: Univerzita Tomáše Bati ve Zlíně, 14.-15.4. 2008, s. 196-201, ISBN 80-7318-697-5.

[2] KOLAROVSZKI, P., HNATOVÁ, Z. Umiestnenie a orientácia RFID štítkov ako jeden z faktorov úspešného snímania poštových zásielok, In: Postpoint 2009: Globalization - a chance for postservices!?: Žilina, 16.-18.9.2009

[3] PLICA J., Vplyv elektromagnetického vlnenia na funkčné vlastnosti RFID zariadení, diplomová práca, Žilinská univerzita, katedra spojov, 2010

[4] TENGLER J. Identifikace poštovních zásilek prostřednictvím technológie RFID, diplomová práca, Žilinská univerzita, katedra spojov, 2010

\section{Grantová podpora:}

- 077-059ŽU-4/2010 - Implementácia nových technológií do vzdelávania (vytvorenie RFID laboratória ako podporného prvku pre vzdelávanie)

- OPV-2009/1.2/01-SORO - Systematizácia pokrokových technológií a poznatkov medzi priemyselnou sférou a univerzitným prostredím

- 089-068ŽU-4/2010 Aplikácia RFID pri sledovaní pohybu diplomových a bakalárskych prác v rámci univerzitného campusu 